\title{
Effects of Different Drip Irrigation Quotas on Soil Water Distribution and Growth and Development of Pear-jujube
}

\author{
Shenglan $\mathrm{Ye}^{*}$ \\ Shaanxi Provincial Land Engineering Construction Group Co., Ltd Xi'an, 710075, china. \\ Institute of Land Engineering and Technology, Shaanxi Provincial Land Engineering Construction \\ Group Co., Ltd Xi'an, 710075, china. \\ Key Laboratory of Degraded and Unused Land Consolidation Engineering, the Ministry of Land \\ and Resources Xi'an, 710075, china. \\ Shaanxi Provincial Land Consolidation Engineering Technology Research Center, Xi'an 710075, \\ China. \\ *552769044@qq.com
}

\begin{abstract}
In order to study the efficient water-saving drip irrigation system of pear-jujube in the loess hilly region of northern Shaanxi, the eight-year-old pear-jujube tree was used as the research object to study the soil water distribution and pear water content of different dates of drip irrigation (100, 135 and $180 \mathrm{~m}^{3} / \mathrm{hm}^{2}$ ) in pear jujube forest. It effected the jujube growth and development. The results showed that the average soil water content of high, medium and low irrigation quota before and after irrigation was higher than that of un-irrigated land by $1.95 \%, 1.92 \%$ and $1.66 \%$, respectively. The average soil moisture content of high, middle and low irrigation levels in soil layers at $0-100 \mathrm{~cm}$ depth increased by $4.90 \%, 4.01 \%$, and $2.63 \%$ compared with CK, respectively. There was no significant difference in the growth rate of jujube between the three irrigation treatments during the whole monitoring period, but they were all significantly higher than those of CK. The water consumption increases with the increase of irrigation quota, while the law of water consumption strength and the law of water consumption are not the same. The average water intensity of the high, middle and low irrigation quota treatments was $1.12,0.88$, and $0.69 \mathrm{~mm} / \mathrm{d}$, higher than that of no irrigation. The highest yield of high irrigation quota was $16772.80 \mathrm{~kg} / \mathrm{hm}^{2}$. The output of jujube trees treated with high, medium and low irrigation quotas increased by $6.00 \%, 5.28 \%$, and $4.37 \%$, respectively, compared with no irrigation. The water use efficiency of jujube trees with high, medium and low irrigation rates was $1.32,1.55$, and $1.73 \mathrm{~kg} / \mathrm{m} 3$, respectively. The irrigation yield of jujube trees with high irrigation quota was increased by $1.56 \%$, and the irrigation water production efficiency was reduced by $23.71 \%$. Better plan with low irrigation quota.
\end{abstract}

Keywords: Drip irrigation, pear-jujube, water distribution characteristics, growth and development.

\section{Introduction}

Zizyphus Mill is a traditional fruit in China. The production of red dates in China accounts for 99\% of the world's production and accounts for $100 \%$ of international trade. Pear-jujube is an important fresh food species of red dates. The fresh dates are large, crisp and sweet, rich in vitamins, minerals, and phenolic substances. Some authors pointed out that the quality of the fruit, especially the jujube, in arid and semi-arid areas is mainly affected by irrigation [1-2].

For a long time, the current situation of water shortage has seriously hindered the sustainable development in northern Shaanxi. The area has deep soil layers, deep water table, annual average precipitation of $400-550 \mathrm{~mm}$, and annual average evaporation of $1000-1200 \mathrm{~mm}$ [3]. The amount of water resources is $890 \mathrm{~m}^{3}$, which is equivalent to $40.5 \%$ of the national average level, and it is a resource-deficient area [4]. Pear-jujube is a high-quality fruit tree in Yulin Mountain. It is one of the best tree species that takes into account both economic and ecological value. However, the lack of drought in the jujube area seriously restricts the further development of the jujube industry. The research on the water-saving and efficient irrigation system is of great significance to overcoming this bottleneck. At present, the modern drip irrigation system has been initially applied in the irrigation of jujube trees, but the cultivation techniques of water-saving irrigation in the jujube garden are still not mature enough, and blindly imitating the irrigation methods of other crops during the 
production process has produced many negative effects on the jujube garden, such as The roots moved upwards, and the branches and leaves passed over. Many scholars have done a lot of research on the application of drip irrigation technology in jujube [5-10]. This study explored the soil water content of different irrigation quotas and the growth and development of jujube trees in order to meet the local conditions of drip irrigation system in northern Shaanxi.

\section{Materials and Methods}

\subsection{Test Design}

The test tree is an 8-year-old pear tree. The test tree is required to be uniform. The radius and height of the tree canopy are about $160 \mathrm{~cm}$ and $200 \mathrm{~cm}$ respectively. The jujube tree is arranged by double drip irrigation. The dripper is located at the left and right side of the trunk at about $20 \mathrm{~cm}$. The dripper flow rate is $4 \mathrm{~L} / \mathrm{h}$, jujube drip irrigation layout shown in Figure 1 . The test set four different treatments that was table 1. Each treatment was 3 groups repeated.

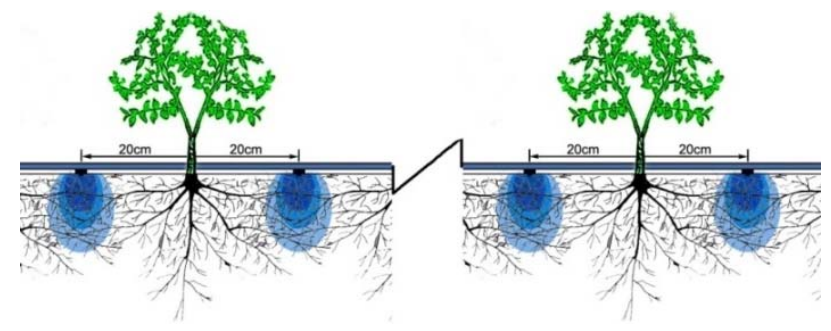

Fig.1 Sketch map of drip irrigation arrangement of jujube

Table.1 Experimental treatments

\begin{tabular}{ccccccc}
\hline Number & $\begin{array}{c}\text { Irrigation } \\
\text { quota }\left(\mathrm{m}^{3} / \mathrm{hm}^{2}\right)\end{array}$ & $\begin{array}{c}\text { Irrigation } \\
\text { frequency }\end{array}$ & $\begin{array}{c}\text { Sprouting leaf } \\
\text { stage }\end{array}$ & $\begin{array}{c}\text { Flowering fruit } \\
\text { setting }\end{array}$ & $\begin{array}{c}\text { Expansion } \\
\text { period }\end{array}$ & $\begin{array}{c}\text { Mature } \\
\text { period }\end{array}$ \\
\hline N1 & 100 & 4 & 1 & 2 & 1 & 0 \\
N2 & 135 & 4 & 1 & 2 & 1 & 0 \\
N3 & 180 & 4 & 1 & 2 & 1 & 0 \\
N4 & & & & & & \\
\hline
\end{tabular}

\subsection{Observation Indicators and Methods}

Soil Moisture Content: The method of soil drying with soil drilling is used. The depth of determination is $100 \mathrm{~cm}$, and every $10 \mathrm{~cm}$ is a measurement point. The monitoring point is located about $20 \mathrm{~cm}$ around the trunk near the earth, and the measurement time is before irrigation and 24 hours after irrigation, when rainfall occurs. It was measured after 24 hours of rainfall.

Hanging length: it was measured with a steel ruler with an accuracy of $0.1 \mathrm{~cm}$. Sample selection used three directions in four directions of the southeast and northwest, and finally taking the average value. It was measured from June 1 to June 26 for 7 times, every 3 days measured, the interval time is appropriately extended as the jujube hangs and the leaf growth rate slows down. Number of flowers and fruits: Statistics the number of flowers and fruits in the whole test tree. Yield: The jujube tree yield was determined by first counting the whole jujube fruit number, and then randomly sampling 30 weighed to obtain the average fruit weight, thus yielding the yield. The measurement time was September 30, 2014. 


\section{Results and Analysis}

\subsection{Characteristics of Soil Moisture Movement of Jujube Trees with Different Drip Irrigation and Irrigation Quota}

\subsubsection{Effects of Irrigation Quota on Soil Water Distribution in Drip Irrigation of Jujube Trees}

Figure 2 shows the average soil moisture content of jujube trees before and after irrigation at different irrigation quotas. It can be seen that the regularity of soil water content in jujube trees before and after irrigation with different irrigation quotas is: high irrigation quota $\left(180 \mathrm{~m}^{3} / \mathrm{hm}^{2}\right)>$ medium irrigation quota $\left(135 \mathrm{~m}^{3} / \mathrm{hm}^{2}\right)>$ low irrigation quota $\left(100 \mathrm{~m}^{3} / \mathrm{hm}^{2}\right)>\mathrm{CK}$, the average soil moisture content of $0-100 \mathrm{~cm}$ treated with high, medium and low irrigation levels before irrigation was $1.59 \%$, $1.54 \%, 1.02 \%$ higher than that of unirrigated land. The initial moisture content of high irrigation quotas is higher. After the irrigation volume is increased, the gradients of surface and deep water potentials increase, and the infiltration rate is fastest. Followed by the irrigation quota treatment, the lowest irrigation quota treatment is the slowest, high, medium and low irrigation quota treatment after irrigation for 24 hours after infiltration to $80 \mathrm{~cm}, 70 \mathrm{~cm}$ and $60 \mathrm{~cm}$. Because the planned wetting layer is designed to be $60 \mathrm{~cm}$, the surface layer $0-60 \mathrm{~cm}$ has relatively high moisture content. Jujube root system main water absorption area, low irrigation quota treatment due to the relatively small amount of irrigation, soil moisture content in the depth range of $20-60 \mathrm{~cm}$ significantly reduced; $60-90 \mathrm{~cm}$ for the root water absorption transition layer, the treatment of soil moisture content are reduced to varying degrees, Below $90 \mathrm{~cm}$ basically stable, there is a rising trend; and unirrigated $0-100 \mathrm{~cm}$ soil moisture content basically decreases with increasing soil depth.

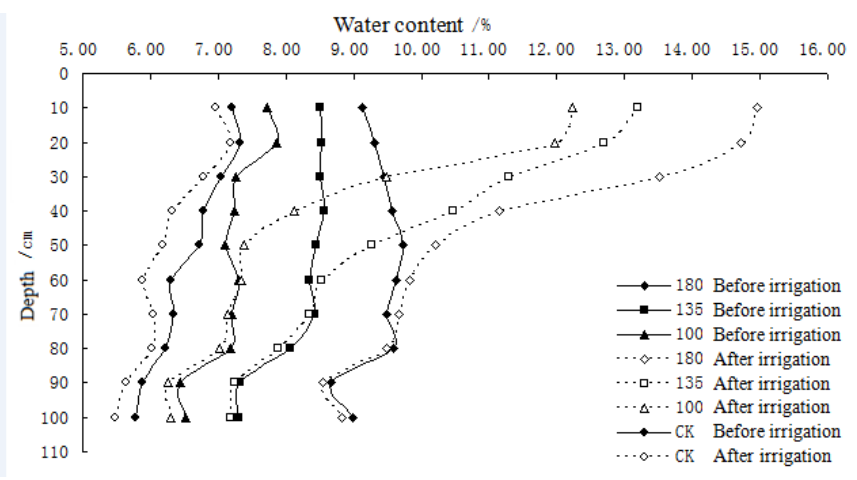

Fig. 2 Average water content of jujube before and after irrigation in the whole growth period

\subsubsection{Effect of Drip Irrigation Quota on Soil Moisture in the Whole Growth Period}

The results showed that: according to the sensitivity of rainfall, irrigation and evaporation, it boils down to $0-30 \mathrm{~cm}$ as the moisture variable layer, $30-60 \mathrm{~cm}$ as the transition layer, and $60-100 \mathrm{~cm}$ as the relatively stable layer. Fig. 3 shows the change of soil water content of jujube at different depths in the whole growth period. It can be seen that the soil moisture with the highest irrigation quota has the highest soil moisture content at different depths. With the deepening of the soil depth, the water content changes. Slowing shrieking $0-30 \mathrm{~cm}$ soil is affected by irrigation, rainfall and evaporation, and the soil moisture content changes most violently; $30-60 \mathrm{~cm}$ is the main active layer of the root system. The supply of soil moisture is relatively sufficient for high and medium irrigation quotas, and it is different from the treatment of low irrigation quotas and more apparent than the surface. The average soil moisture content of high-, medium-, and low-irrigated soil layers at depths of $0-100 \mathrm{~cm}$ was $4.90 \%, 4.01 \%$, and $2.63 \%$ higher than that of CK respectively. 


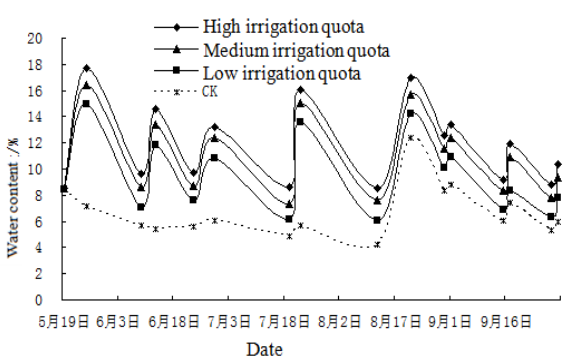

(a) $0 \sim 30 \mathrm{~cm}$

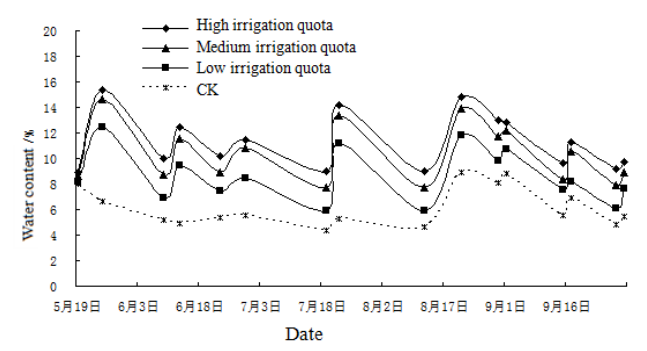

(b) $30 \sim 60 \mathrm{~cm}$

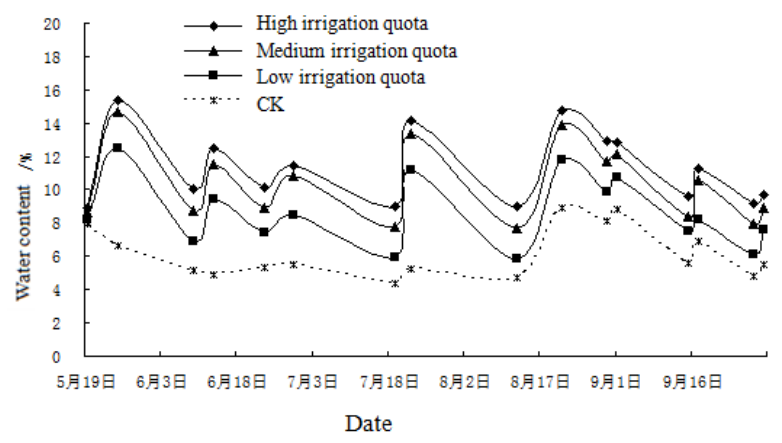

(c) $60 \sim 100 \mathrm{~cm}$

Fig. 3 Average water content of different irrigation quota treatments in the whole growth period

\subsection{Effect of Irrigation Quota on Growth and Development of Jujube}

\subsubsection{Influence of Irrigation Quota on the Growth of Jujube}

The description in this paper uses relative growth rates. It was $[(n+1)$ observations- $n$ observations $] / \mathrm{n}$ times. Observations Fig. 4 shows the dynamic changes of different irrigation quotas during the vigorous growth period of jujube hanging until the growth is slow and stable. It can be seen that the general trend of jujube hanging growth is rapid growth from early morning and gradually slowing down later. The tendency to stabilize is that the jujube suspension treated with irrigation is significantly faster than CK. The relative growth rates of jujube cranes between different irrigation quota treatments are reversed in the fore-and-aft period. The high-irrigation quotas have a slower growth in the early stage of jujube hanging, and are treated faster than the middle and low irrigation quotas, which may be due to the influence of temperature. In the early growth stage of jujube, in addition to the unfavorable factors of low soil moisture content caused by persistent drought in early spring, the slow recovery of temperature also greatly inhibited the growth of jujube. CK due to the continuous drought caused the lowest relative growth rate of jujube, and the high Jujube trees treated with irrigation quotas have lower growth rates in the early stage due to lower temperature and lower irrigation quotas. In the later period, as the temperature continues to rise, the rate of growth of the high-irrigation quotas tends to be the fastest. . Due to the interaction of temperature and moisture, the growth rate of jujube hanging between the three irrigation treatments showed no significant difference during the whole monitoring period, but it was significantly higher than that of CK. The average value of the relative growth rate of jujube hangings treated with high, medium and low irrigation quotas compared with $\mathrm{CK}$, they increased by $0.04,0.05$, and 0.04 respectively. 


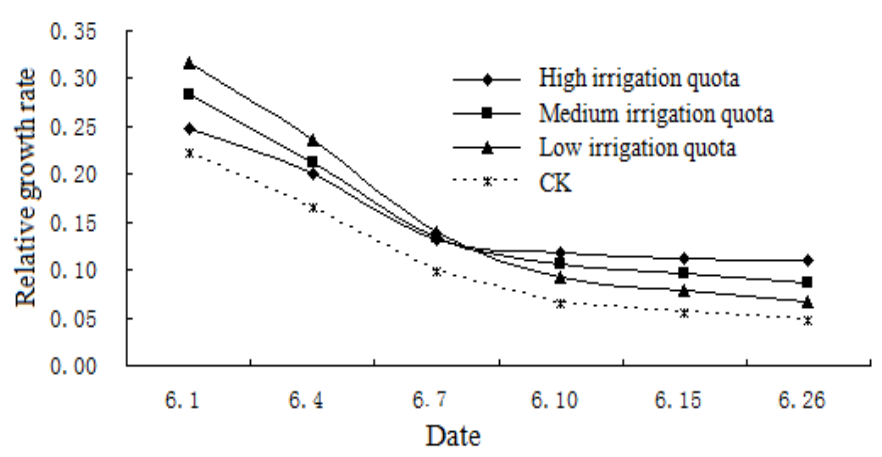

Fig. 4 The relative growth rates of different irrigation quota treatment jujube hangers

\subsubsection{Effects of Different Irrigation Quotas on Fruit Setting Rate of Jujube Trees}

Table 2 reflects the situation of fruiting of individual jujube trees treated with different irrigation quotas. It can be seen that a prominent feature of the physiological reproductive growth of jujube trees is that the number of flowering is numerous and the fruit setting rate is extremely low. The fruit setting rate of different treated jujube trees is only 1.38-2.84. The order of fruit setting rate among different treatments was as follows: high irrigation quota treatment $>$ medium irrigation quota treatment $>$ low irrigation quota treatment $>\mathrm{CK}$, and the three treatment fruit setting percentages were $\mathrm{CK} 1.46 \%, 1.23 \%$, and $0.79 \%$, respectively. In addition, it can be seen that the drought-deficient water of CK has greatly promoted the increase of flowering amount. However, the soil moisture is low, and the function of the tree body to absorb moisture and lower its own temperature is poor, resulting in a large loss of fruit set. Therefore, during the fruit setting period, moisture is a key factor affecting its fruit set so as to affect its final yield.

Table.2 The percentage of fruit of different irrigation quota treatment jujube

\begin{tabular}{cccc}
\hline irrigation quota $/\left(\mathrm{m}^{3} / \mathrm{hm}^{2}\right)$ & flowers & Fruit number & Fruit setting rate $/ \%$ \\
\hline 180 & 30563 & 868 & 2.84 \\
135 & 32567 & 850 & 2.61 \\
100 & 32488 & 705 & 2.17 \\
CK & 39130 & 540 & 1.38 \\
\hline
\end{tabular}

\subsubsection{Influence of Irrigation Quota on Yield of Jujube}

Table 3 shows the calculation results of water consumption, water intensity, yields and water use efficiency of drip irrigation jujube trees. It can be seen that the water consumption increases with the increase of the irrigation quota, and the water consumption in each growth period is in accordance with the law of water consumption modulus. Because of the difference in the number of days of each growth period, the law of water intensity and the law of water consumption are not the same. The fruiting and fruit setting period is short, the cell division is fierce, the water demand is large, and the water intensity is also the greatest. In the second stage of inflating, the minimum leaf stage was budding, and the average water consumption intensity of high, medium and low irrigation treatments was $2.60,2.35$ and $2.17 \mathrm{~mm} / \mathrm{d}$, respectively, which was $1.12,0.88$, and $0.69 \mathrm{~mm} / \mathrm{d}$ larger than that of no irrigation. The highest yield of high irrigation quota was $16772.80 \mathrm{~kg} / \mathrm{hm} 2$. The output of jujube trees treated with high, medium and low irrigation quotas increased by $6.00 \%, 5.28 \%$, and $4.37 \%$, respectively, compared with no irrigation. Considering the water consumption of irrigation and rainfall, the water use efficiency increases with the decrease of water consumption. The production efficiency of irrigation water increases with the decrease of irrigation quota. The water use efficiency of jujube trees with high, middle and low irrigation quotas is 1.32 , respectively. For 1.55 and $1.73 \mathrm{~kg} / \mathrm{m} 3$, the output of jujube trees with high irrigation quotas and irrigation water quotas increased by $1.56 \%$ and irrigation water production efficiency decreased by $23.7 \%$ and $71 \%$ respectively. If the irrigation efficiency is lower, the irrigation quotas scheme is better. 
Table. 3 The yield and water use efficiency of different irrigation quota treatment jujube

\begin{tabular}{|c|c|c|c|c|c|c|}
\hline Treatment & Index & $\begin{array}{l}\text { Sprouting } \\
\text { leaf stage }\end{array}$ & $\begin{array}{l}\text { Floweri } \\
\text { ng fruit }\end{array}$ & $\begin{array}{l}\text { Fruit } \\
\text { growth } \\
\text { period }\end{array}$ & $\begin{array}{c}\text { Fruit } \\
\text { maturit } \\
\mathrm{y}\end{array}$ & $\begin{array}{l}\text { Total } \\
\text { growth } \\
\text { period }\end{array}$ \\
\hline \multirow{7}{*}{$\begin{array}{l}\text { High } \\
\text { irrigation } \\
\text { quota }\end{array}$} & $\begin{array}{c}\text { Water } \\
\text { consumption } / \mathrm{mm}\end{array}$ & 46.50 & 111.97 & 139.65 & 104.98 & 403.10 \\
\hline & Days/d & 34 & 30 & 59 & 36 & 159 \\
\hline & $\begin{array}{l}\text { Water consumption } \\
\text { intensity } / \mathrm{mm} \cdot \mathrm{d}^{-1}\end{array}$ & 1.37 & 3.73 & 2.37 & 2.92 & 2.60 \\
\hline & $\begin{array}{l}\text { Water consumption } \\
\text { modulus } / \%\end{array}$ & 11.54 & 27.78 & 34.64 & 26.04 & 100.00 \\
\hline & Yields $/ \mathrm{kg} \cdot \mathrm{hm}^{-2}$ & & & & & 16772.80 \\
\hline & $\begin{array}{c}\text { Water use } \\
\text { efficiency } / \mathrm{kg} \cdot \mathrm{m}^{-3}\end{array}$ & & & & & 4.16 \\
\hline & $\begin{array}{c}\text { Water } \\
\text { consumption } / \mathrm{mm}\end{array}$ & & & & & 1.32 \\
\hline \multirow{7}{*}{$\begin{array}{l}\text { Medium } \\
\text { irrigation } \\
\text { quota }\end{array}$} & $\begin{array}{c}\text { Water } \\
\text { consumption } / \mathrm{mm}\end{array}$ & 37.10 & 105.45 & 126.24 & 98.54 & 367.33 \\
\hline & Days/d & 33 & 30 & 58 & 35 & 156 \\
\hline & $\begin{array}{l}\text { Water consumption } \\
\text { intensity } / \mathrm{mm} \cdot \mathrm{d}^{-1}\end{array}$ & 1.12 & 3.51 & 2.18 & 2.82 & 2.35 \\
\hline & $\begin{array}{l}\text { Water consumption } \\
\text { modulus } / \%\end{array}$ & 10.10 & 28.71 & 34.37 & 26.83 & 100.00 \\
\hline & Yields $/ \mathrm{kg} \cdot \mathrm{hm}^{-2}$ & & & & & 16658.20 \\
\hline & $\begin{array}{c}\text { Water use } \\
\text { efficiency } / \mathrm{kg} \cdot \mathrm{m}^{-3}\end{array}$ & & & & & 4.53 \\
\hline & $\begin{array}{c}\text { Water } \\
\text { consumption } / \mathrm{mm}\end{array}$ & & & & & 1.55 \\
\hline \multirow{7}{*}{$\begin{array}{l}\text { Low } \\
\text { irrigation } \\
\text { quota }\end{array}$} & $\begin{array}{c}\text { Water } \\
\text { consumption } / \mathrm{mm}\end{array}$ & 30.00 & 94.58 & 111.72 & 93.93 & 330.23 \\
\hline & Days/d & 31 & 28 & 58 & 35 & 152 \\
\hline & $\begin{array}{l}\text { Water consumption } \\
\text { intensity } / \mathrm{mm} \cdot \mathrm{d}^{-1}\end{array}$ & 0.97 & 3.38 & 1.93 & 2.68 & 2.17 \\
\hline & $\begin{array}{l}\text { Water consumption } \\
\text { modulus } / \%\end{array}$ & 9.08 & 28.64 & 33.83 & 28.44 & 100.00 \\
\hline & Yields $/ \mathrm{kg} \cdot \mathrm{hm}^{-2}$ & & & & & 16514.50 \\
\hline & $\begin{array}{c}\text { Water use } \\
\text { efficiency } / \mathrm{kg} \cdot \mathrm{m}^{-3}\end{array}$ & & & & & 5.00 \\
\hline & $\begin{array}{c}\text { Water } \\
\text { consumption } / \mathrm{mm}\end{array}$ & & & & & 1.73 \\
\hline \multirow{6}{*}{$\mathrm{CK}$} & $\begin{array}{c}\text { Water } \\
\text { consumption } / \mathrm{mm}\end{array}$ & 27.40 & 50.01 & 79.32 & 56.17 & 212.90 \\
\hline & Days/d & 27 & 28 & 56 & 33 & 144 \\
\hline & $\begin{array}{l}\text { Water consumption } \\
\text { intensity } / \mathrm{mm} \cdot \mathrm{d}^{-1}\end{array}$ & 1.01 & 1.79 & 1.42 & 1.70 & 1.48 \\
\hline & $\begin{array}{l}\text { Water consumption } \\
\text { modulus } / \%\end{array}$ & 12.87 & 23.49 & 37.26 & 26.39 & 100.00 \\
\hline & Yields $/ \mathrm{kg} \cdot \mathrm{hm}^{-2}$ & & & & & 15822.30 \\
\hline & $\begin{array}{c}\text { Water use } \\
\text { efficiency } / \mathrm{kg} \cdot \mathrm{m}^{-3}\end{array}$ & & & & & 7.43 \\
\hline
\end{tabular}




\section{Conclusion}

1. The regularity of soil water content of jujube trees before and after irrigation is: high irrigation quota $\left(180 \mathrm{~m}^{3} / \mathrm{hm}^{2}\right)>$ middle irrigation quota $\left(135 \mathrm{~m}^{3} / \mathrm{hm}^{2}\right)>$ low irrigation quota $\left(100 \mathrm{~m}^{3} / \mathrm{hm}^{2}\right)>\mathrm{CK}$.

And in different depths of soil layer, the soil moisture content of the high irrigation quota is the highest. With the deepening of the soil depth, the water content changes gradually.

2. The growth rate of jujube hanging between three irrigation treatments showed no significant difference during the whole monitoring period, but it was significantly higher than that of CK. The fruit-setting rate is high irrigation quota $>$ medium irrigation quota $>$ low irrigation quota $>C K$.

3. The water consumption and the water consumption module increase with the increase of the irrigation quota. But the law of water consumption intensity and the law of water consumption are not the same. The average water consumption intensity of the high, middle and low irrigation quota treatment period is lower than that of CK. The production efficiency of irrigation water increased with the reduction of irrigation quota. The output of jujube with high irrigation quota was lower by only $1.56 \%$, while the irrigation water production efficiency decreased by $23.71 \%$.

Therefore, considering the comprehensive research data and the local water shortage situation, considering the economic efficiency, the low irrigation quota scheme is more suitable for the irrigation of local jujube gardens.

\section{References}

[1]. Zhezhou Qu, Yonghui Wang. Chinese Fruit Tree Records: Jujube Rolls. China Forestry Publishing House,1993,p.2-6.

[2]. Yuxin Guo. Ziziphus jujuba Mill.[M]. China Forestry Publishing House,1982, p.3-5.

[3]. Zhiyuan Ma, Yingdong Xu, Jijiao Fan. Shaanxi Water Resources Distribution and Sustainable Development and Utilization. northwestern geology. Vol. 34(2003) No.4, p.96 100.

[4]. Xuetian Gao, Fenli Zhen. Eco-environment construction and sustainable agriculture development in the Loess Plateau of northern part of shaanxi province.Research of soil and water conservation. Vol.11(2004) No.4, p.47 49.

[5]. Pute $\mathrm{Wu}$, Youke Wang, Xiaogui Xin, et al. Integration and demonstration of the date microirrigation technology in the hilly of Shanbei. Agricultural research in the arid areas. 2008,Vol.26 (2008) No.4, p.1-6.

[6]. Cai Zhongping, Wang Xuemei, Sun Xia, et al. Study on pattern of requirement of fertilizer in Zizyphus jujube growth period under drip irrigation condition. Southwest China journal of agricultural sciences. Vol.23(2010) No.2,p.493-496.

[7]. Yongfa Li, Long Wang, Xiaoyan Yan, et al. Distribution characteristic of nitrogen under lightsaline water trickle irrigation in the root area of Jujub.Journal of tarim university. Vol. 22(2010) No.1,p.14-15.

[8]. Junfa Ma, Defu Zhang. Techniques for drip irrigation and seedling cultivation of hami jujube under film.Northwest horticultrue, Vol.(2010) No.1, p.14-15.

[9]. Chen Jiang, Guohong Liu, Xiangwen Xie, et al. Research on micro-irrigation method for grown red jujube in drought area. Xinjiang agricultural sciences, Vol.46(2009) No.2, p.332-337.

[10]. Qiangqin Zhen, Qiling Chen, Ming Li, et al. Water requirement law and drip irrigation system of drip irrigation jujube. Jiangsu Agricultural Sciences, Vol.41(2013) No.11,p.187-189. 